\title{
Мистецтвознавство
}

UDC 008: 130.2

\author{
Afonina Olena \\ Doctor in Art Studies \\ Associate professor of \\ National Academy of Managerial Staff \\ of Culture and Arts \\ ORCID 0000-0003-1627-6362 \\ aolena7@gmail.com
}

\section{“FOLK CODES” IN THE MUSICAL MATERIAL OF MODERN BALLETS}

The purpose of the article is to highlight the folklore codes in the musical material of modern ballets. Methodology is based on the use of benchmarking methods; generalizations for the conceptualization and expansion of the meaning of "folklore codes" in modern ballets. The scientific novelty of the work consists in the actualization of "folklore codes" in E. Stankovic's ballet music and the content of modern ballets R. Poklitaru, M. Schroeder. Conclusions. Based on the analysis of modern ballets, "folklore codes", which are contained in the title and libretto of the works and musical material, are revealed. In the musical material, composers refer to quotations of folk intonations and their transformations, which are more reminiscent of allusions or reminiscences of folklore material. First, the names of the works suggest recipients to the perception of images, which are revealed by "folklore codes" as information historically established. For authors, the use of folk material becomes the process of identifying additional meanings of known codes. The use of "folklore codes" in the symbolic art of dance includes hidden components of the sign system - movements, costumes, stage design, which helps the viewer to plunge into the world of allusions and fairy tales, revealing the contents of the works.

Key words: "folklore codes"; musical material; folklore material; modern ballet; libretto.

Афоніна Олена Сталівна, доктор мистецтвознавства, доцент, доцент Національної академії керівних кадрів культури і мистецте

«Фольклорні коди» в музичному матеріалі сучасних балетів

Мета - виявити «фольклорні коди» в музичному матеріалі сучасних балетів. Методологія роботи ґрунтується на використанні методів порівняльного аналізу; узагальнення для концептуалізації і розширення змістів «фольклорних кодів» у сучасних балетах. Наукова новизна роботи полягає в актуалізації фольклорних кодів у балетній музиці $€$. Станковича, Ю. Шевченка і змісті сучасних балетів Р. Поклітару, М. Шрьодера. Висновки. Ґрунтуючись на аналізі сучасних балетів, виявлені «фольклорні коди», які містяться в назві, лібрето творів і музичному матеріалі. У музичному матеріалі композитори звертаються до цитат народних інтонацій та їх трансформацій, які більше нагадують алюзії або ремінісценції на фрольклорний матеріал. В першу чергу назви творів наштовхують реципієнтів на сприйняття образів, які розкриваються «фольклорними кодами» як інформацією історично усталеною. Для авторів використання фольклорного матеріалу стає процесом виявлення додаткових смислів відомих кодів. Вживання «фольклорних кодів» у символічному мистецтві танцю включає в себе приховані компоненти знакової системи - рухів, костюмів, сценічного оформлення, що допомагає глядачеві зануритися в світ алюзій і казки при розкритті змісту творів.

Ключові слова: «фольклорні коди»; музичний матеріал; фольклорний матеріал; сучасний балет; лібрето.

Афонина Елена Стальевна, доктор искусствоведения, доцен, доцент Национальной академии руководящих кадров культуры и искусств

«Фольклорные коды» в музыкальном материале современных балетов

Цель статьи - выделить фольклорные коды в музыкальном материале современных балетов. Методология работы основывается на использовании методов сравнительного анализа; обобщения для концептуализации и расширение смыслов «фольклорных кодов» в современных балетах. Научная новизна работы заключается в актуализации «фольклорных кодов» в балетной музыке Е. Станковича и содержании современных балетов Р. Поклитару, М. Шредера. Выводы. Основываясь на анализе современных балетов, выявлены «фольклорные коды», которые содержатся в названии и либретто произведений и музыкальном материале. В музыкальном материале композиторы обращаются к цитатам народных интонаций и их трансформациям, которые больше напоминают аллюзии или реминисценции на фольклорный материал. В первую очередь названия произведений наталкивают реципиентов на восприятие образов, которые раскрываются «фольклорными кодами», как информацией исторически устоявшейся. Для авторов использование фольклорного материала стает процессом выявления дополнительных смыслов известных кодов. Применение «фольклорных кодов» в символическом искусстве танца включают скрытые компоненты знаковой системы - движения, костюмы, сценичное оформление, что помогает зрителю окунуться в мир аллюзий и сказки, раскрывая содержание произведений.

Ключевые слова: «фольклорные коды»; музыкальный материал; фольклорный материал; современный балет; либретто

The «folklore code» is a system for transmitting historically accumulated information in music, dance, fairy tales, proverbs and other forms of folk art. Folk music has preserved a whole arsenal of recognizable folk samples in vocal (song), instrumental and dance forms. Folklore existed in oral (unlisted) form and was transmitted by the performers, creating the conditions for the multivariate interpretation. At all times, folklore codes are used by composers and performers in the form of citations. Therefore, to decode the content of new works, the appeal to musical folklore as an art of ethnocultural codes, images, meanings, events, into- 
nations, rhythmic formulas, form codes and the process of establishing associative links is relevant. In ballets, folklore codes can be distinguished in music and the libretto.

The music code, as a well-established structure, is capable of transmitting information. In music, this refers to musical intonation, which was considered by Boris Asafiev as historically variable and was interconnected with changes in the intonational field of time. It turns out that folklore, including music, is very resistant to all kinds of changes. This is most likely because musical intonations were born based on intonational language and folkloric intonations encompass a complex that combines intonations of singing and speaking. In the main music, there is intonation playback. Everything is important in folklore: music, word, and intonation, which covers

A wide range of musical expressiveness. These include pitch, rhythmic and timbre colors, aimed at an emotional and semantic meaning for perception. Therefore, in the analysis of musical works the concept of the "genetic code of the genre» is often used. For folklore, it is generally very important.

Folk codes in the genres of fairy tales, songs, dance contained code images, for example, grandfather and woman as goodies. Negative images that have a contradictory communicative process between themselves and oppose positive images. So in music or movements, it is quite difficult to reveal positive and negative things - these are more symbolic things, revealed with the help of well-known plot images. With the help of character codes, the moral categories of good and evil are introduced. "Folklore codes" in music and choreography combine character codes and image codes that help trigger the coding process through repeated and varied repetition of situations. In music, this repetition of intonations is accurate and interpreted. In choreography, this is a repetition of movements and actions. The action can be repeated as an exact reprise, or it can be repeated as an interpretation of the previous action.

Art historians and musicologists write about the Ukrainian ballet music of authors: A. Plakhotnyuk, M. Pogrebnyak, Yu. Stanishevsky, A. Chepalov, D. Sharikov, A. Shabalina, S. Shalapa. Many articles are devoted to the premiere performances.

Ukrainian scholar Elena Zinkevich writes about the form of ballet Yevgeny Stankovic «May Night» as "a series of folk - genre sketches - lyrical and comic, chamber and mass. Almost every plot situation, the portrait of the character Stankovic "grows» from a certain folk song sample. It can be said that he "danced" the Ukrainian song (can the ballet "melt"?) ... Behind the external unpretentiousness of this handsome lyrical and comedy opus is a thoroughly professional work that shows Stankovich's inherent orchestral ingenuity and the ability to "melt" the folklore thematics into the new quality» [2, p. 145].

In the folk-ballet «May Night» E. Stankovic sounds in a chorus, which serves as a participant, an event commentator, a means of musical drama and a unique sound paint in the general score [1].

For example, the critic Anna Nikulina writes about Yevgeny Stankovic's ballet «Evenings on a farm near Dikanka»: "The genre fantasy allows you to explore not only the traditions of the holiday but also the political context, social roles and gender relations with the help of humor and extraordinary scenario» [3].

The music of Yury Shevchenko's ballet "For Two Hares" has become the embodiment of urban folklore codes, but for the most part copyright. For example, the song "In the sky the canary flies" by composer Vadim Gomolyaki became the leit of all ballet music. Intonations of gallop, polka, waltz, funeral march create the atmosphere of the whole ballet. Or music for children's ballets by Andrei Bondarenko, which contains a whole arsenal of folklore codes, for example, in the theme of Mukha-Tsekotukhy from the ballet of the same name. The music of these worthy authors when using folklore codes in it makes it possible to acquaint listeners with a new development of well-known material. But today, listeners are often not familiar with the musical material.

Folk codes are found in E. Stankovic's ballet «The Lord of Borisfen», where the composer turns to ritual mass scenes: the ritual worship of the god Perun, the feast of the Slavs with the Huns, and a carnival festival in Rome. To characterize the image of the guslar, on behalf of which the narration is being conducted, the composer used high-dull intonations. Such traditions were characteristic of the musical and theatrical art of the XIX century. On the subject of Slavs, E. Stankovic turned to song melos and characterized the Huns with orchestral means and rhythms.

The purpose of the article is to highlight folklore codes in the music and the content of modern ballets.

Ukrainian composer Yevhen Stankovych addressed the plot of Gogol's «Evenings on a Farm Near Dikanka» in the ballet "The Night Before Christmas» (1990). The first incarnation on the stage was the music of E. Stankovic's ballet in 1993 (Kiev) under the direction of choreographer Viktor Litvinov. A new version of the fantasy ballet with the new title «Evenings on a farm near Dikanka» and a supplemented final appeared in 2015.

For the best display of the pre-holiday evening on the eve of Christmas, the composer uses the wellknown songs «Shchedryk», "Rejoice, earth». The emotional color and plotline of Gogol's story are very finely recreated in the music of ballet. There is nothing surprising in this since the verbal texts have already become code for the Christmas holidays. Although in the process of existence certain changes took place, still the folk codes - text and music - were shaped like every system of socially significant stereotypes by collective memory (Y. Lotman). 
The music of E. Stankovic turned the performance into a ballet extravaganza with romantic and comically ironic scenes. The ballet is based on the romantic love of the blacksmith Vakula and the beautiful Oksana, the daughter of a rich Cossack, who sends the lover Vakula to St. Petersburg for the Queen's shoes. «In fact, a funny ballet - so you can say about this work. Stankovic felt the penetrating penetration of Gogol's laughter - with all his "registers" from a slight smile to rolling laughter, from ingenious fun to a keen grotesque» [2, c. 149].

Ballet E. Stankovic "Christmas Eve" consists of two actions. It has a lot of humor and lyrics, which was laid in the story of N. Gogol. A lot of humor in scenes Solokhi and Devil. Their duet conveys a rich acting game. Solokha plays with the Devil: he rides him, catches up with and overtakes his "thoughts". Therefore, after the Chairman, Diak and Chub are knocking each other to her, her attempts to dodge are perceived as a continuation of the game with evil spirits. Of course, here the composer uses folk dance melodies, which further reveals scenes of folk traditions. Since some stories from Nikolai Gogol's cycle "Evenings on a farm near Dikanka" (1829-1931) were often embodied in musical and theatrical performances, it is mentioned that in 1873 there was a competition to write the best opera based on Gogol's novel «Christmas Eve». At that time, P. Tchaikovsky's opera "The Slippers" (in the first edition of "Koval Vakula", 1874) was awarded the first prize. In his music, the composer turned to Ukrainian folklore. And it is very interesting that he used Hopak in the scene Devil and Solokhi and Duma - in Vakula's aria, "The girl hears your heart." As in the classical ballet, each image received a leitmotif, reflecting the character. In the scene of the meeting between Solokha and Chub, an interpretation of Ukrainian folk dance is easily guessed.

The second action of the ballet begins with the promise of the Blacksmith Vakula to release the Devil after receiving shoes for her bride, Oksana, from Queen Catherine II. A trip to Petersburg brings to mind a dance of stars from the opera of the same name by N. Rimsky-Korsakov.

And here it is worth remembering that the fairy-tale opera by N. Rimsky-Korsakov with the same name in the genre "true story" (in 1895). Appeared only after Tchaikovsky's death. In the story of Gogol acted real and fantastic characters. N. Rimsky-Korsakov in his own libretto strengthened the fantastic element, creating for the unreal heroes - the round dance of the stars, the sky train of Ovsen and Kolyada - a lot of music with interesting melodic harmonic finds. Against the background of caroling, Oksana orders Vakula to find shoes for her from the queen. The carol sounds in the scene Solokhi and the Devil «We will steal a month from the sky». In the scene of the flight of Vakula and Devil also sounds a carol. The carol became a building material in N. Rimsky-Korsakov. Folk codes through figurative, musical, poetic signs and symbols often have their roots in mythological (after F. Buslaev) or historical heroes (L. Maikov, V. Miller).

And now, a hundred years later, in the production of E. Stankovic's ballet, similar scenes with modern dance movements were used in the production. Choreographer V. Litvinov turns to modern dance in fantastic episodes. In general, the second action is perceived as a kind of reflection of the first action. Although the first pass in the village, and the second in the palace, it seems that the authors wanted to show how the human factor does not depend on social status. In the first act, in the simple rural house, Solokha flirts with the Devil and his officials. There is a lot of humor in the scene. In the second act, the queen is already playing with her subordinates. The place has changed, but not the action itself. Only now it's not so much humor as satire in action, which is very well conveyed by Stankovic's musical numbers. The comic and unusual situation is transferred to the musical characteristics of Solokha using the saxophone tone. Leather theme Solokhi and Devil have their own dramatist function. For example, in the music of the first action in the scene, Solokhi and the Devil are combined intonations of folk and popular music with howling intonations of the saxophone. This creates several effects at once: comic, fantastic and psychological.

Music conveys a whole world of feelings of different heroes: the doubts and fear of Vakula, the love, and hate of the queen, subordinates, free Cossacks and even the Devil. The scene of the ball is striking in its psychological essence. Only music rules the ball. And it already causes completely different memories.

The masterly movements of the dances of Vakula and the Cossacks are contrasted with the rustic and uninteresting movements of the queen and her retinue. Incredibly small and even caricature looks all the pomposity of the royal chambers. The whole scene in the palace gives the impression of something historically artificial, implausible. At the maid of honor, the masks are on the back of their heads, which is interpreted as "double truth, truth with a double bottom", hypocrisy.

In the music of the scene of the queen with her favorites through the theme of the palace sounds intonation, reminiscent of howls from the musical theme of Solokha. This is symbolic, because Solokha also danced, though in turns, but with four partners. Now the queen is dancing, and the impression is that it "hangs" with four partners at once.

An interesting dance is Vakula and Tsarina with Oksana, who is assigned the role of a passive participant, the role of memory. Although throughout the performance, Oksana's dances differed in organic classical freedom using movements of modern and folk choreography. Her flight corresponded to the free nature of a girl in love. In Stankovic's music, the image of Oksana is revealed in various intonation spheres. Oksana - Vakula's lover and a girl in love with him are characterized by lyrical intonations that are more suited to the realm of modern music, including the Soviet intonations of the 1980s. Primir, in Monoloza of the first act Oksana, admires in the mirror. Against the background of successive movement in the xylophone accompaniment, the flute solo sounds. High register, recurring melodic intonations of the flute paint the number in the 
colors of the inaccessibility of the dream, but this is only before the appearance of Vakula. In Adagio, with the inclusion of the stringed group in the general fabric, musical development becomes harmonious. The lyrical beginning is interrupted by the intonations of the approaching fiction.

Oksana, who dreams of the Queen's shoes, is characterized by an intonational sphere that is closer to fantastic images. For example, during the general scene of the national holiday, Vakula appears with a bag, in which the Devil and representatives of the rural authorities are located. When Oksana appears in front of the audience in love, then her intonational sphere and her movements are lyrical.

In general, the music of the composer is very diverse and filled with a large supply of musical codes. Behind Stankovic's words in an interview with Olga Golinskaya, his ballet-pastiche «Evenings on a Farm Near Dikanka» evokes associations with the pastiche-opera that existed in the 18th century. The famous melodies «Rosamund», "Rio-Rita», intonations of the Soviet song «We are not firemen, not carpenters» are guessed on to the ear.

Folklore codes in E. Stankovic's music, like that of many other composers, are related to the display of folklore rites characteristic of events in ballet. For example, in I. Stravinsky in the ballet "Spring sacred», musical intonations manifest the essence of communicative archetypes and are universal semiotic codes. Thus, in the first part of "The Kiss of the Earth», the repetitions, variable accentuation with intonations of conscription, as well as intonations are dominant. These intonations cause direct associations with the prologue of N. Rimsky-Korsakov's musical fairy tale "Snow Maiden», where the composer builds the musical fabric of the kingdom of Berendey with the voices of Spring-Red and birds. Stankovic uses carols - because in ballet the content of the action takes place the night before Christmas. The folklore code is the name of the ballet as the famous novel by Gogol.

Christmas codes are often used in titles of works, for example, in the one-act ballet of the German choreographer Mario Schroeder «Christmas Carol» (2011) based on the story by Charles Dickens. The choreographer uses the music of different composers, but it is quite well known and is also certain codes. The costumes of the artists resemble contemporary paintings with dominant colors (blue, yellow and others), which is also part of the Christmas codes.

In this regard, we can recall the one-act ballet "Long Christmas Dinner» by Radu Poklitaru based on the play by the classic American literature Thornton Wilder. In the ballet, on the material of the traditional Christmas holiday, the history of the family is played out from birth to death, where Death has a major, final role in life. The ballet takes place with the music of Antonio Vivaldi "The Seasons". The language of dance tells the parable about the century of life of the Bayard family. The life of the characters is perceived as a change from one Christmas to another - with a constant turkey. Couples change at the table, but the tradition of celebrating Christmas with a turkey does not change. Christmas Eve ends with love, from which children appear, continuing the genus Bayard. At the table first sits Mother, who later the maid takes out in a wheelchair. It is significant that the maid becomes the main actor. She sets the festive table, takes a new life, takes her on her last journey, keeps the course of life and death, their alternation.

In this ballet R. Poklitaru, there are very few choreographies proper: the dancers run, sing to the music of A. Vivaldi, but there is a lot of pantomime and theater. The codes used by the choreographer (music by A. Vivaldi, the literary source of the play, the feast of the Nativity) consciously set the postmodernist style on their ironic comparison. After all, information in the artistic practice of postmodernism consists of code systems - the source and its rethinking. They just «twice» encode this postmodern text for the viewer. Therefore, the presentation of R. Poklitaru is increasingly becoming a ballet, but a theatrical one. Such a synthesis of the semiotic concept of a literary text, in this case of a play by Thornton Wilder, with an ironic Pasteish in a new sense in the form of a ballet performance.

So, based on the analysis of modern ballets on the problems of using folklore codes in them, we can draw the following conclusions. Folk codes are contained in the title and the libretto of works and musical material. Among the methodological approaches to the study of folklore codes on the musical material of modern ballets, it is necessary to single out the methods of comparative analysis with a projection on the history of culture and art as the main one. In musical and ballet art, folklore codes include the hidden components of the sign system - symbols, images, tales, allusions or quotations that reveal the content of the works. Music has its own sign-semantic system of folklore codes, organically presented in modern ballet music. Therefore, folklore codes in ballet music through semiotic, semantic and communicative components form the transfer of information in the chain of the author - the work - the performer - the recipient.

\section{תimepamypa}

1. Голинська О. Євген Станкович: “Балет як мистецтво буде жити стільки, скільки житиме людство, музика” // Український інтернет-журнал «Музика», 6.04.2016 URL: http://mus.art.co.ua/evhen-stankovych-balet-yak-mystetstvo-bude-zhyty-stilkyskilky-zhytyme-lyudstvo-muzyk (дата обращения: 11.02.2019).

2. Зинькевич Е. Симфонические гиперболы: О музыке Евгения Станковича. Сумы, 1999. 252 с.

3. Никулина A. Ревью: "Вечера на хуторе близ Диканьки" в Национальной опере Украины URL: https://balletristic.com/revju-vechera-na-hutore-bliz-dikanki-v-nacionalnoj-opere-ukrainy/ (дата обращения: 11.02.2019). 


\title{
References
}

1. Golinskaya O. (2016). Yevhen Stankovych: "Ballet as art will live as humanity, music". Ukrainian Internet magazine "Muzika", April 6, 2016 URL: http://mus.art.co.ua/evhen -stankovych-balet-yak-mystetstvo-bude-zhyty-stilky-skilky-zhytyme-lyudstvo-muzyk [in Ukrainian].

2. Zinkevich E. (1999). Symphonic hyperbole: About the music of Yevgeny Stankovich. Sumy [in Russia].

3. Nikulina A. (2017). Review: "Evenings at a farm near Dikanka" at the National Opera of Ukraine URL: https://balletristic.com/revju-vechera-na-hutore-bliz-dikanki-v-nacionalnoj-opere-ukrainy [in Ukrainian].

Стаття надійшла до редакції 19.09.2018 p.

УДК $78.03(78)$

\author{
Андросова Дарія Володимирівна \\ доктор мистецтвознавства, професор \\ Одеської національної музичної академії \\ імені А.В.Нежданової \\ ORCID 0000-0002-5951-8416 \\ dashaelena@gmail.com
}

\section{КУЛЬТУРА ФРАНЦІї НА ЗЛАМІ ХІХ І ХХ СТОЛІТЬ У ФОРМУВАННІ КОНЦЕПЦІЇ ФОРТЕПІАННИХ КОНЦЕРТІВ К. СЕН-САНСА}

Метою роботи є усвідомлення органіки ліричної концепції фортепіанного концерту у французькій культурі кінця XIX початку XX століття, представленої фортепіанними Концертами К. Сен-Санса, актуальне інтонування яких визначено «неосимволізмом» (за О.Марковою) поставангарда останніх десятиліть. Методологічною основою роботи $є$ інтонаційний підхід школи Б.Асафььева в Україні. Базисне місце займає метод жанрово-стильового порівняльного аналізу, герменевтический метод, а також позиції виконавського аналізу, як це представлено в працях В.Медушевського, О.Марковой, а також у роботах С.Скребкова та ін. Наукова новизна роботи визначена тим, що вперше в музикознавстві України співвідноситься інтонаційний стрій протосимволізму, символізму й неосимволізму початку XXI сторіччя в конкретиці трактування жанру концерту у творчості К. СенСанса, уперше представлена органіка зв'язку адраматических тенденцій мислення Сен-Санса із прорелігійним тонусом культури символізму і його прояву в неосимволізмі сучасності. Висновки. Твори Сен-Санса становлять стильово-значеннєву паралель до прояву концертного жанру у російських, українських композиторів, для яких типологія концерту також виключала трагіко-драматичне наповнення, була спрямована до екстатично-радісного «передзвону» фріналу, черпаючи з атмосфери довіри до релігійної екстатики, затвердженої символізмом. У Сен-Санса самостійне значеннєве наповнення одержують фактурні прийоми, що утворюють саме тематичні показники, підводячи до концепції «розсередженого тематизму» XX ст. Якість ігрової єдності мистецтво-реальність постмодерна у пост-поставангарді перетворюється в пафосне піднесення «життєвої вірогідності» у зв'язку із саме художнім текстом. Відповідно, у виконавському репертуарі одержала особливе визнання музика концертноошатна, що співвідноситься з радісно-компенсативним тонусом розважального - і духовного мистецтва, ємно представленого концентністю музики К. Сен-Санса.

Ключові слова: культура Франції кінця XIX - початку XX століття; символізм - неосимволізм XXI ст.; жанр фоортепіанного концерту; стиль у музиці; популярне мистецтво.

Андросова Дария Владимировна, доктор искусствоведения, професссор Одесской национальной музыкальной академии имени А.В.Неждановой

Культура Франции на сломе XIX и XX веков в формировании концепции фортепианныХ концертов К.Сен-

Санса

Целью работы является осознание органики лирической концепции фортепианного концерта во французской культуре конца XIX - начала XX века, представленной фортепианными Концертами К.Сен-Санса, актуальное интонирование которых определено «неосимволизмом» (по Е.Марковой) поставангарда последних десятилетий. Методологической основой работы является интонационный подход школы Б.Асафьева в Украине. Базисное место занимает метод жанрово-стилевого сравнительного анализа, герменевтический метод, а также позиции исполнительского анализа, как это представлено в трудах В.Медушевского, Е.Марковой, Д.Андросовой, а также в работах С.Скребкова и др. Научная новизна работы определена тем, что впервые в музыкознаниии Украины соотносится интонационный строй прото-символизма, символизма и неосимволизма начала XXI столетия в конкретике трактовки жанра концерта в творчестве К.Сен-Санса, впервые представлена органика связи адраматических тенденций мышления Сен-Санса с прорелигиозным тонусом культуры символизма и его проявления в неосимволизме современности. Выводы. Произведения Сен-Санса составляет стилево-смысловую параллель к проявлению концертного жанра у русских, украинских композиторов, для которых типология концерта также исключала трагико-драматическое наполнение, была устремлена к экстатически-радостному «перезвону» финала, черпая из атмосферы доверия к релоигиозной экстатике, утвержденной символизмом. У Сен-Санса самостоятельное смысловое наполнение получают фрактурные приемы, образующие собственно тематические показатели, подводя к концепции «рассредоточенного тематизма» XX в. Качество игрового единства искусство-реальность постмодерна, в пост-поставангарде претворяется в пафоосное преподнесение «жизненной достоверности» в единстве с собственно художественным текстом. Соотвественно, в исполнительском репертуаре получила особое признание музыка концертно-нарядная, соотносимая с радостно-компенсативным тонусом развлекательного - и духовного искусства, емко представленного концентностью музыки К.Сен-Санса.

Ключевые слова: культура Франции конца XIX - начала XX века; символизм - неосимволизм XXI ст.; жанр фортепианного концерта; стиль в музыке; популярное искусство.

Androsova Daria, Doctor of Study of Art, Professor of the Odessa National A. V. Nezhdanova Academy of Music

Culture to France on demolition XIX and XX century in formation of the concepts to piano concerto of C.Saint-Saëns

The purpose of the article is a realization of naturalness to lyrical concept of a piano concerto in French culture end XIX begin XX century, presented piano Concerto of C.Saint-Saëns, actual intonation which is determined "neosymbolism" (on E.Markova) of post-vanguard last decennial event. The methodology of the work is the intonation approach of the school B.Asafiev in Ukraine. The base place occupies the method of the genre-style comparative analysis, hermeneutics method, as well as positions performance anal-

() Андросова Д. В., 2019 